Государственная власть. Законодательный процесс...

Удк 340

DOI https://doi.org/10.17308/vsu.proc.law.2020.2/2794

\title{
ОБЩЕСТВЕННЫЙ КОНТРОЛЬ: ПРАКТИКА, ПРОБЛЕМЫ, НАПРАВЛЕНИЯ СОВЕРШЕНСТВОВАНИЯ
}

\author{
Ю. В. Агибалов
}

Воронежский институт экономики и социального управления,

Российская академия народного хозяйства и государственной службь при Президенте Российской Федерации (Воронежский филиал)

Поступила в редакцию 20 апреля 2020 г.

\begin{abstract}
Аннотация: статья посвящена анализу действующего законодательства, регулирующего вопросы осуществления общественного контроля, а также роли и месту общественных палат как субгектов общественного контроля. Расслатривается практика осуществления общественного контроля в Воронежской области. Выявлены проблемы и предложены пути повышения эффбективности осуществления общественного контроля общественныли палатами и направления совершенствования действующего законодательства.
\end{abstract}

Ключевые слова: общественный контроль, субгекты, общественные палатьь.

\begin{abstract}
: the article is devoted to the analysis of the current legislation regulating the implementation of public control, the role and place of public chambers as subjects of public control. The article deals with the practice of public control in the Voronezh region. The article identifies problems and suggests ways to improve the effectiveness of public control by public chambers and ways to improve the current legislation.

Key words: social control, subjects, of the public chamber.
\end{abstract}

В последние годы в научной и специальной литературе появились работы, посвященные вопросам осуществления общественного контроля и месту общественных палат среди институтов гражданского общества в России. Роль общественных палат в системе общественного контроля, практику взаимодействия общественных палат с органами публичной власти, осуществление общественного контроля в системе местного самоуправления и на выборах в органы власти исследует в своих работах Г. Н. Чеботарёв ${ }^{1}$. Т. Н. Михеева уделяет большое внимание проблемам формиро-

${ }^{1}$ См.: Чеботарёв $\Gamma$. Н. Общественная палата в системе общественного контроля субъекта Российской Федерации // Рос. юрид. журнал. 2015. № 6 (105). C. 125-130) ; Его же. Общественный контроль в системе местного самоуправления // Конституционное и муниципальное право. 2017. № 9. С. 45-48; Его же. Общественный контроль на выборах : опыт и проблемы правового регулирования // Там же. 2018. № 7. С. 56-60 ; Его же. Общественный контроль за деятельностью органов публичной власти : от теории к практике // Там же. 2015. № 8. С. 62-65 ; Его же. Организационно-правовые формы взаимодействия общественных палат с органами публичной власти // Государство и право. 2018. № 12. С. 151-159.

(C) Агибалов Ю. В., 2020 


\section{Вестник ВГУ. Серия: Право}

вания и деятельности региональных общественных палат, организации и практики осуществления общественного контроля. Роль и место общественных палат в системе общественного контроля исследует В. В. Гриб². Проблемы правового статуса общественных палат нашли отражение в работах А. Ф. Малого, Т. Н. Малой ${ }^{3}$; становления института общественных палат, статуса и гарантий деятельности членов общественных палат - в статьях И. В. Решетниковой ${ }^{4}$; деятельности общественных советов при органах власти посвятили свои работы И. В. Тепляшин ${ }^{5}$ Е. Г. Дьякова, А. Д. Трахтенберг ${ }^{6}$, Т. Н. Михеева, Р. В. Горнев ${ }^{7}$ и др.

О необходимости организации действенного общественного контроля, создании при федеральных и региональных органах исполнительной власти общественных советов говорил в своих ежегодных Посланиях Федеральному Собранию РФ Президент РФ В. В. Путин ${ }^{8}$. На встрече с членами Общественной палаты РФ 25 июня 2017 г. он подчеркнул, что: «...она не должна подменять собой ни правительство, ни парламент, у нее должна быть своя ниша, и эту нишу она занимает. Это общественный контроль за тем, что делают исполнительные и представительные органы власти, и прямая связь с людьми» ${ }^{9}$.

${ }^{2}$ См.: Гриб В. В. Место и роль общественных палат в системе общественного контроля в Российской Федерации // Конституционное и муниципальное право. 2015. № 5. C. 33-38,

${ }^{3}$ См.: Мальй А. Ф., Малая Т. Н. Общественная палата субъекта Российской Федерации : некоторые проблемы определения правового статуса // Конституционное и муниципальное право. 2017. № 5. С. 38-41.

${ }^{4}$ См.: Решетникова И. В. Гарантии деятельности членов общественных палат // Юрист. 2017. № 2 ; Ее же. Становление института общественных палат субъектов Северо-Кавказского федерального округа // Государственная власть и местное самоуправление. 2017. № 1. С. 48-53.

${ }^{5}$ См.: Тепляшин И. В. Общественные советы в системе субъектов общественного контроля // Государственная власть и местное самоуправление. 2019. № 9. C. 3-7; Его же. Участие институтов гражданского общества в формировании общественных советов при органах государственной власти : основные способы и некоторые проблемы // Рос. юстиция. 2018. № 6. С. 5-8.

${ }^{6}$ См.: Дьякова Е. Г., Трахтенберг А. Д. Общественные советы при исполни-

58 тельных органах власти : рецепция федерального законодательства на региональном уровне (на примере Уральского федерального округа // Рос. юрид. журнал. 2016. № 2. С. 68-77.

${ }^{7}$ См.: Михеева Т. Н., Горнев Р. В. К вопросу о формировании общественных советов при органах местного самоуправления // Рос. юстиция. 2015. № 8. С. 9-11.

${ }^{8}$ Послание Президента РФ Федеральному Собранию от 12 декабря 2013 г. URL: http://www.consultant.ru/cons/cgi/online.cgi?req=doc\&base=LAW\&n=155646\& $\mathrm{fld}=134 \& \mathrm{dst}=1000000001,0 \& \mathrm{rnd}=0.7884486850902579 \# 09440348994865109$ (дата обращения: 06.12.2019).

${ }^{9}$ Владимир Путин : роль Общественной палаты РФ в общественном контроле за действиями органов власти и прямой связи с людьми. URL: https://www.1tv. ru/news/2017-06-25/327651-vladimir_putin_rol_obschestvennoy_palaty_rf_v_ obschestvennom_kontrole_za_deystviyami_organov_vlasti_i_pryamoy_svyazi_s_ lyudmi (дата обращения: 06.12.2019). 
Государственная власть. Законодательный процесс...

Реализуя задачи, поставленные Президентом РФ В. В. Путиным, в России была сформирована нормативно-правовая база, позволяющая на практике повысить статус институтов гражданского общества в части осуществления общественного контроля, расширить возможности $\mathrm{HKO}^{10}$. Правовое регулирование деятельности институтов гражданского общества осуществляют и субъекты РФ.

На основе действующего законодательства, существующей практики становления и развития общественного контроля в Российской Федерации нами проведено исследование практики осуществления общественного контроля институтами гражданского общества в Воронежской области.

\section{Общественный контроль в Воронежской области: правовое регулирование и субъекты}

В Воронежской области создана необходимая правовая база, позволяющая институтам гражданского общества участвовать в осуществлении общественного контроля за работой органов власти, а также оказывать влияние на правотворческую деятельность. Уставом Воронежской области правом законодательной инищиативы наделены: Общественная палата Воронежской области, Торгово-промышленная палата Воронежской области, Союз «Воронежское объединение организаций профсоюзов», Союз сельскохозяйственных товаропроизводителей Воронежской области, представительные органы муниципальных образований. Право законодательной инициативы в областной Думе принадлежит также уполномоченному по правам человека в Воронежской области по вопросам компетенции ${ }^{11}$. Право на гражданскую инищиативу в форме коллективного обращения в органы государственной власти и в органы местного самоуправления Воронежской области, в том числе право на отзыв депутата, выборного должностного лица местного самоуправления, предоставлено гражданам РФ ${ }^{12}$, а право законодательной инициативы по вопросам внесения поправок в Устав Воронежской области - избирателям ${ }^{13}$. Населению и институтам гражданского общества законодательством Воронежской области предоставлено право на участие в обсуждении общественно значимых вопросов

${ }^{10}$ Об основах общественного контроля в Российской Федеращии : федер. закон от 21 июля 2014 г. № 212-Ф3// Собр. законодательства Рос. Федерации. 2014. № 30 (ч. 1). Ст. 4213 ; Об общих принщипах организащии и деятельности общественных палат субъектов Российской Федерации : федер. закон от 23 июня 2016 г. № 183Ф3 // Там же. 2016. № 26 (ч. 1). Ст. 3852 ; О внесении изменений в Федеральный закон "О некоммерческих организациях" в части установления статуса некоммерческой организации - исполнителя общественно полезных услуг : федер. закон от 3 июля 2016 г. № 287-Ф3// Там же. 2016. № 27 (ч. 1). Ст. 4220 ; О внесении изменений в отдельные законодательные акты Российской Федерации по вопросам добровольчества (волонтерства) : федер. закон от 5 февраля 2018 г. № 15-ФЗ // Там же. 2018. № 7. Ст. 975.

${ }^{11}$ Статья 34 Устава Воронежской области. URL: http://ww.govvrn.ru (дата обращения: 01.12.2019).

12 Там же. Статья 10.

${ }^{13}$ Там же. Статья 82. 


\section{Вестник ВГУ. Серия: Право}

и проектов нормативных правовых актов органов государственной власти $^{14}$, а также на проведение независимой экспертизы проектов законов, иных нормативных правовых актов Воронежской области ${ }^{15}$.

Законом Воронежской области от 5 июня 2015 г. № 103-О3 «О регулировании отдельных вопросов осуществления общественного контроля в Воронежской области» ${ }^{16}$ в качестве субъектов общественного контроля определены: Общественная палата Воронежской области, общественные палаты муниципальных образований Воронежской области, общественные советы при Воронежской областной Думе, общественные советы при исполнительных органах государственной власти области. Эти общественные объединения наделены всеми правами в части осуществления общественного контроля, закрепленными Федеральным законом № 212-Ф3 ${ }^{17}$ : общественный мониторинг, общественные проверки, общественные экспертизы и др.

В Воронежской области сформирована и осуществляет свою деятельность Общественная палата Воронежской области. В муниципальных районах и городских округах сформированы общественные палаты, а при органах государственной власти и местного самоуправления - общественные советы. Положения об этих общественных институтах, их правовом статусе и порядке деятельности закрепляются нормативными правовыми актами соответствующих органов.

\section{Участие институтов гражданского общества в законотворческой деятельности.}

\section{Общественная әкспертиза нормативно-правовых актов.}

Практика работы органов государственной власти показывает, что принятие нормативных правовых актов, призванных регулировать важнейшие общественные отношения в различных сферах экономики и по-

N литики, прав и интересов граждан и общественных организаций, требует серьезного анализа как возможных последствий от их принятия, так и реакции общества. При әтом исключительно важное значение имеет согласование социальных интересов по принципу формальной свободы в их реализации, когда свобода одних в реализации своих интересов не нарушает свободу других. Эту задачу невозможно решить органам власти без

60 тесного взаимодействия с институтами гражданского общества. Очевидно, что согласование интересов гражданского общества и власти - не простой

${ }^{14} \mathrm{O}$ народном обсуждении проектов нормативных правовых актов Воронежской области и важнейших вопросов социально-экономического развития Воронежской области : закон Воронежской области от 27 ноября 2008 г. № 120-О3 // Молодой коммунар. 2008. 29 нояб.

${ }^{15} \mathrm{O}$ Торгово-промышленной палате Воронежской области : закон Воронежской области от 18 июля 2016 г. № 99-O3. URL: http://www.govvrn.ru

${ }^{16}$ URL: http://www.govvrn.ru

${ }^{17}$ Об основах общественного контроля в Российской Федерации : федер. закон от 21 июля 2014 г. № 212-Ф3 // Собр. законодательства Рос. Федерации. 2014. № 30 (ч. 1). Ст. 4213. 
Государственная власть. Законодательный процесс...

процесс. Это возможно только в случае взаимной заинтересованности и ответственности как со стороны власти, так и гражданского общества. Ярким примером является обсуждение Общественной палатой Воронежской области вопроса о создании лесопаркового зеленого пояса г. Воронежа, в соответствии с законодательством Воронежской области ${ }^{18}$. Проведение публичных слушаний показало, что вопрос определения лесопаркового пояса г. Воронежа оказался не простым, так как различные группы граждан видели его решение исходя из собственных взглядов и интересов. Проводимая в течение двух лет Общественной палатой работа позволила найти разумный компромисс, и было принято постановление Воронежской областной Думы ${ }^{19}$.

Общественная палата области, обладая правом законодательной инициативы в Воронежской областной Думе ${ }^{20}$, может непосредственно вносить в Воронежскую областную Думу разработанные ею законопроекты, а также поправки к законопроектам, принятым в первом чтении; проводить общественную әкспертизу законопроектов и нормативно-правовых актов органов государственной власти и местного самоуправления. В соответствии с законом области об Общественной палате Общественная палата проводит экспертизу проектов законов Воронежской области о поправках к Уставу Воронежской области, а также проектов законов Воронежской области, затрагивающих следующие вопросы:

1) региональной сощиально-экономической политики и прав граждан в области социального обеспечения;

2) обеспечения общественной безопасности и правопорядка ${ }^{21}$.

Анализ практики реализащии Общественной палатой области предоставленных ей прав показал, что основной акцент делается на рассмотрение законопроектов и нормативно-правовых актов, направляемых органами государственной власти. Право законодательной инициативы в Воронежскую областную Думу используется крайне редко. По инищиативе Общественной палаты области в областной Думе было рассмотрено и принято три закона области.

${ }^{18} \mathrm{O}$ лесопарковых зеленых поясах городских населенных пунктов в Воронежской области : закон Воронежской области от 6 июля 2017 г. № 92-O3. URL: ttps:// www.govvrn.ru ; Об Общественной палате Воронежской области и о признании утратившими силу отдельных законодательных актов Воронежской области : закон Воронежской области от 16 декабря 2016 г. № 169-O3. URL: https://www. govvrn.ru

${ }^{19} \mathrm{O}$ создании лесопаркового зеленого пояса города Воронежа и о его площади : постановление Воронежской областной Думы от 7 марта 2019 г. № 1665-VIОД. URL: https://www.govvrn.ru

${ }^{20} \mathrm{O}$ поправках к Уставу Воронежской области : закон Воронежской области от 5 июня 2015 г. № 96-O3. URL: http://www.pravo.gov.ru

${ }^{21}$ Статья 22 Закона Воронежской области от 16 декабря 2016 г. № 169-ОЗ (в ред. от 13.09.2019) «Об Общественной палате Воронежской области и о признании утратившими силу отдельных законодательных актов Воронежской области». URL: https://www.govvrn.ru 


\section{Вестник ВГУ. Серия: Право}

В настоящее время в России сложилась практика так называемого «нулевого» чтения. По мнению специалистов, она достаточно эффективна с точки зрения повышения скорости законодательного процесса, так как законопроект приходит в законодательный орган уже доработанным. Процедура “нулевого» чтения активно применяется на практике при формировании проекта федерального закона о бюджете на очередной финансовый год, несмотря на то что в Бюджетном кодексе Российской Федерации норм, касающихся "нулевого» чтения, нет ${ }^{22}$. Реакция общества на новый закон, по мнению Секретаря Общественной палаты РФ Л. М. Михеевой, должна быть выявлена и доведена до законодателя на стадии инициативы, а не тогда, когда закон опубликован и вступает в силу ${ }^{23}$.

В Воронежской области недостаточно внимания уделяется участию населения и институтов гражданского общества в рассмотрении законопроектов на стадии "нулевого чтения", несмотря на то что в порядке, предусмотренном Законом Воронежской области от 27 ноября 2008 г. № 120-О3 «О народном обсуждении проектов нормативных правовых актов Воронежской области и важнейших вопросов социально-экономического развития Воронежской области» ${ }^{24}$ ежегодно проводятся публичные слушания по законам: о проекте бюджета на очередной финансовый год и плановый период; о проекте отчета об исполнении областного бюджета. Одной из причин является то, что население не верит, что его мнение будет услышано и учтено. Анализ правовой базы, регулирующей деятельность Общественной палаты Воронежской области, показал, что в нем имеются существенные пробелы. Так, ни в Регламенте Воронежской областной Думы, ни в Регламенте правительства Воронежской области не прописан механизм рассмотрения заключений Общественной палаты по результатам проведения общественной әкспертизы нормативных правовых актов. Заключение, подготовленное по результатам общественㄱй экспертизы, в соответствии со ст. 22 Закона № 169-ОЗ, направляется

글 на рассмотрение губернатору Воронежской области, в органы государственной власти Воронежской области, органы местного самоуправления, государственные и муниципальные организации, иные органы и организации, осуществляющие в соответствии с федеральными законами отдельные публичные полномочия, и обнародуется в соответствии с Фе-

62 деральным законом № 212-Ф3, в том числе размещается в информащионно-телекоммуникационной сети «Интернет» ${ }^{25}$. Однако в законодательстве области отсутствует механизм рассмотрения заключений Общественной

${ }^{22}$ См.: Болтинова О. В. Становление и развитие бюджетного законодательства Российской Федерации // Актуальные проблемы российского права. 2015. № 3. С. 74-82.

${ }^{23}$ Главой Общественной палаты стала заслуженный юрист РФ Лидия Михеева. URL: https://www.oprf.ru/press/news/2019/newsitem/51801 (дата обращения: 10.12.2019).

${ }^{24}$ Молодой коммунар. 2008. 29 нояб.

${ }^{25}$ Статья 22 Закона Воронежской области от 16 декабря 2016 г. № 169-ОЗ (в ред. от 13.09.2019) «Об Общественной палате Воронежской области и о признании 
Государственная власть. Законодательный процесс...

палаты по результатам проведенных общественных экспертиз. Аналогичная ситуация наблюдается и на федеральном уровне ${ }^{26}$. Субъекты Федерации самостоятельно пытаются регулировать эти вопросы в региональном законодательстве ${ }^{27}$.

Очевидно, что сегодня необходимо не только совершенствовать действующее законодательство, но и обеспечить реальный механизм учета мнения общественных палат при осуществлении законотворческого процесса.

Для повышения роли Общественной палаты и значения проведенной общественной экспертизы предлагается закрепить в областном законодательстве обязанность органов государственной власти и местного самоуправления рассматривать в порядке, установленном законом или регламентом органа власти, заключения по результатам общественной экспертизы, с непосредственным участием представителя Общественной палаты, проводившего экспертизу нормативно-правового акта. С такой законодательной инициативой в областную Думу могла бы выйти Общественная палата Воронежской области. При наличии такой нормы, можно было бы оценивать работу общественной палаты по осуществлению общественной экспертизы.

\section{Осуществление общественного мониторинга и контроля} за реализацией национальных проектов в Воронежской области

Необходимость проведения общественного мониторинга как одной из форм общественного контроля сегодня очевидна. Актуальность этой работы связана с реализацией в России Национальных проектов. Однако в настоящее время осуществление общественного контроля со стороны общественных палат оставляет желать лучшего. Поэтому не случайно Президент РФ В. В. Путин, обращаясь к членам Правительства РФ, заявил, «что практика общественного и гражданского контроля за работой правительства должна продолжаться. Вы должны также подавать пример конструктивного сотрудничества со структурами гражданского общества, с политическими партиями, в том числе и с Общероссийским народным фронтом как одной из наиболее массовых общественных организаций. Активисты ОНФ имеют большой опыт контроля за реализацией майских указов 2012 г. Уверен, что такую практику, практику гражданского об-

утратившими силу отдельных законодательных актов Воронежской области». URL: https://www.govvrn.ru

${ }^{26}$ См.: Агибалов Ю. В. О формировании механизмов, обеспечивающих участие Общественной палаты Российской Федерации, общественных палат субъектов Российской Федерации в экспертизе законопроектов и государственных решений, в том числе в рамках "нулевого» чтения // Вестник Воронеж. гос. ун-та. Серия: Право. 2015. № 4 (23). С. 15-28.

${ }^{27}$ См.: Агибалов Ю. В. О роли и месте общественных палат в субъектах Российской Федерации (на примере Центрального федерального округа) // Регион : системы, әкономика, управление. 2015. № 4 (31). С. 159-164. 


\section{Вестник ВГУ. Серия: Право}

щественного мониторинга и контроля нужно продолжить ${ }^{28}$. Общероссийский народный фронт, не являясь субъектом общественного контроля в отличие от общественных палат, на практике осуществляет общественный контроль.

В Воронежской области есть положительные примеры организации и проведения общественного мониторинга Общественной палатой Воронежской области. Совместно с Воронежским отделением Всероссийской общественной организации ветеранов (пенсионеров) войны, труда, Вооруженных сил и правоохранительных органов Общественной палатой области была проведена независимая общественная оценка состояния паспортизированных воинских захоронений и состояния символических военно-мемориальных объектов, находящихся на территории Воронежской области. Для проведения мониторинга во всех муниципальных районах и городских округах были созданы рабочие группы по проведению мониторинга. В их состав вошли председатели районных общественных палат, представители районных городских советов ветеранов (пенсионеров) войны, труда, Вооруженных сил и правоохранительных органов, женских советов и других общественных организаций. Работа велась в два этапа: в феврале и апреле 2019 г. На первом этапе общественными палатами муниципальных районов (городских округов) Воронежской области совместно с районными ветеранскими организациями было осмотрено 595 паспортизированных воинских захоронений и 737 символических военно-мемориальных объектов в 34 муниципальных районах и городских округах области. По результатам мониторинга 12 паспортизированных воинских захоронений получили оценку “неудовлетворительно». Результаты мониторинга докладывались губернатору области ${ }^{29}$.

Общественная палата Воронежской области, проводит ежегодный мониторинг отношения общественных институтов к деятельности органов местного самоуправления муниципальных районов и городских округов

Z Воронежской области, в рамках исполнения постановления правительства

을 Воронежской области от 26 сентября 2013 г. № 838 «О мониторинге и оцен-

ㅇ ке әффективности развития муниципальных районов, городских округов и поселений, являющихся административными центрами районов Воронежской области» ${ }^{30}$

64 В марте 2019 г. Общественная палата Воронежской области приняла решение провести общественный мониторинг реализации в Воронежской

${ }^{28}$ Путин счел необходимым общественный контроль за работой правительства. URL: https:/lenta.ru/news/2018/05/26/controll/ (дата обращения: 06.12.2019).

29 Общественный мониторинг военно-мемориальных объектов. URL: http:// opvo36.ru/obshhestvennyiy-monitoring-voenno-memorialnyih-obektov (дата обращения: 10.12.2019).

30 О мониторинге и оценке әффективности развития муниципальных районов, городских округов и поселений, являющихся административными центрами муниципальных районов Воронежской области : постановление правительства Воронежской области от 26 сентября 2013 г. № 838. URL: https://www.govvrn.ru 
Государственная власть. Законодательный процесс...

области 11 национальных проектов ${ }^{31}$, для его проведения было предпринято:

- сформировано 11 рабочих групп (в соответствии с профилем реализации национальных проектов на территории Воронежской области), для осуществления общественного контроля за ходом реализащии нащиональных проектов;

- организован информационно-коммуникативный канал, обеспечивающий вовлечение и содействие участию общественности в реализации национальных проектов, выступающий реальным проводником информации для НКО и населения в целом о возможностях участия в национальных проектах в регионе;

- разработана система взаимодействия и координации усилий, обеспечивающих проведение экспертных групп и переговорных площадок на базе общественных советов при профильных департаментах и управлениях, общественных палат разного уровня.

Общественным советам при исполнительных органах государственной власти и местного самоуправления было рекомендовано осуществлять общественный контроль за реализуемыми исполнительными органами национальными проектами ${ }^{32}$.

Для повышения эффективности этой работы председатель Общественной палаты Воронежской области Н. В. Пономарева предложила совместно с профильными департаментами областного правительства сформировать карту результатов мониторинга национальных проектов за 2019 г. и последующие годы, которая будет доступна пользователям в сети «Интернет» на сайтах общественных палат по всему региону.

Насколько эффективно осуществляется общественный контроль в области пока сделать выводы нельзя. Предложение председателя Общественной палаты Н. Пономаревой осталось также без ответа.

\section{Формирование и деятельность общественных советов при исполнительных органах государственной власти: практика и проблемы}

Общественные советы при органах государственной власти (далее Общественные советы) образуются Общественной палатой при взаимодействии с органами власти как постоянно действующие органы общественного контроля, которые позволяют учитывать и согласовывать между собой интересы различных социальных групп, на которые направлены принимаемые органами власти решения.

С принятием Федерального закона № 212-Ф3 Общественная палата РФ и общественные палаты субъектов РФ получили право организовы-

${ }^{31}$ Пленарное заседание Общественной палаты Воронежской области с участием губернатора. URL: http://opvo36.ru/plenarnoe-zasedanie-obshhestvennoy-palatyivoronezhskoy-oblasti-s-uchastiem-gubernatora (дата обращения: 10.12.2019)

${ }^{32}$ Пленарное заседание Общественной палаты Воронежской области. URL: http://opvo36.ru/plenarnoe-zasedanie-obshhestvennoy-palatyi-voronezhskoyoblasti-6 (дата обращения: 10.12.2019). 


\section{Вестник ВГУ. Серия: Право}

вать конкурсы по формированию общественных советов ${ }^{33}$. Порядок формирования бщественных советов в субъектах РФ регулируется: на основе постановлений регионального правительства в Тюменской ${ }^{34}$ и Свердловской областях ${ }^{35}$; на основе закона - в Челябинской области ${ }^{36}$, на основе закона, постановления правительства и положения, утвержденного исполнительным органом государственной власти - в Воронежской ${ }^{37}$. Анализ положений об общественных советах в субъектах РФ показал, что они существенно различаются. В Свердловской области акцент делается на необходимости информирования граждан о деятельности органов власти, участии членов общественных советов в работе конкурсных и аттестационных комиссий, организации и проведении общественной экспертизы; в Курганской области - наиболее часто встречаются указания на обязательность проведения экспертизы нормативных правовых актов, контроля качества государственных услуг и независимой оценки деятельности учреждений сощиальной сферы, информирования о деятельности органов власти; в Тюменской - на общественной экспертизе, информировании граждан и взаимодействии с ними и общественными организациями; в Ханты-Мансийском автономном округе-Югре - на осуществлении экспертизы нормативно-правовых актов; контроле качества государственных услуг и независимой оценке деятельности учреждений социальной сферы; важности противодействия коррупции; в Ямало-Ненецком - на необходимости взаимодействия с гражданами, информировании их о деятельности органов власти и обсуждения основных вопросов и проблем, связанных с ней ${ }^{38}$.

Общественные советы при органах государственной власти Воронежской области как институты гражданского общества образуются в соответствии с Законом Воронежской области от 5 июня 2015 г. № 103 «О регулировании отдельных вопросов осуществления общественного контроля в Воронежской области» (далее - Закон № 103-О3) и иными нормативными

$\checkmark$ правовыми актами Воронежской области, положениями об общественных

${ }^{33}$ О регулировании отдельных вопросов осуществления общественного контроля в Воронежской области : закон Воронежской области от 5 июня 2013 г. № 103. URL: http://www.govvrn.ru

${ }^{34} \mathrm{O}$ порядке образования и Типовых правилах организащии общественных со-

66 ветов при исполнительных органах государственной власти Тюменской области : постановление правительства Тюменской области от 25 апреля 2013 г. № 131-п.

${ }^{35}$ Об утверждении порядка образования общественных советов при областных исполнительных органах государственной власти Свердловской области : постановление правительства Свердловской области от 7 февраля 2014 г. № 65-ПП ; О внесении изменений в постановление правительства Свердловской области от 7 февраля 2014 г. № 65-ПП : постановление правительства Свердловской области от 29 июля 2015 № 691-ПП.

${ }^{36}$ Об общественном контроле Челябинской области : закон Челябинской области от 13 апреля 2005 г. № 155-30.

${ }^{37} \mathrm{O}$ регулировании отдельных вопросов осуществления общественного контроля в Воронежской области : закон Воронежской области от 5 июня 2013 г. № 103. URL: http://www .govvrn.ru

${ }^{38}$ См.: Дьякова Е. Г. Трахтенберг А. Д. Указ. соч. С. 74-75. 
Государственная власть. Законодательный процесс...

советах $^{39}$. В соответствии с нормами ст. 7 Закона № 103-ОЗ общественные советы при исполнительных органах государственной власти Воронежской области формируются на конкурсной основе, если иной порядок формирования общественных советов при отдельных исполнительных органах государственной власти Воронежской области не предусмотрен нормативными правовыми актами губернатора Воронежской области или правительства Воронежской области. Организатором конкурса является Общественная палата Воронежской области. Требования к кандидатурам в состав Общественного совета при исполнительном органе государственной власти Воронежской области разрабатываются соответствующим исполнительным органом государственной власти Воронежской области совместно с Общественной палатой Воронежской области. Правом выдвижения кандидатов в члены общественных советов обладают общественные объединения и иные негосударственные некоммерческие организации, целями деятельности которых являются представление или защита общественных интересов и (или) выполнение экспертной работы в сфере общественных отношений. Состав общественного совета, сформированный из числа кандидатур, отобранных на конкурсной основе, утверждается руководителем соответствующего исполнительного органа государственной власти Воронежской области по согласованию с советом Общественной палаты Воронежской области. Законом определена компетенция общественных советов. Они должны содействовать учету прав и законных интересов общественных объединений, правозащитных, религиозных и иных организаций при общественной оценке деятельности исполнительных органов государственной власти Воронежской области и органов местного самоуправления муниципальных образований Воронежской области. Формирование общественных советов в Воронежской области осуществляется в соответствии с Порядком образования общественных советов при исполнительных органах государственной власти Воронежской области, утвержденным правительством Воронежской области ${ }^{40}$ и Положением об Общественном совете, утвержденном руководителем исполнительного органа государственной власти, в котором определяются компетенция, порядок формирования и деятельности Общественного совета ${ }^{41}$.

Важное значение в деятельности Общественных советов имеет обеспечение их самостоятельности и независимости от органов власти. Без этого невозможно эффективно осуществлять функции общественного контроля и давать объективную общественную оценку деятельности органов власти.

${ }^{39}$ URL: http://www.govvrn.ru

${ }^{40}$ О Порядке образования общественных советов при исполнительных органах государственной власти Воронежской области : постановление правительства Воронежской области от 23 апреля 2019 г. № 399. URL: https://www.govvrn.ru

${ }^{41}$ Об утверждении Положения об общественном совете при государственной жилищной инспекции Воронежской области : приказ Госжилинспекции Воронежской области от 22 июля 2019 г. № 123. URL: http://www.govvrn.ru 


\section{Вестник ВГУ. Серия: Право}

В соответствии с Федеральным законом от 5 декабря 2017 г. № 392-Ф3² общественные палаты субъектов РФ были наделены правом формировать Общественные советы по проведению независимой оценки качества условий оказания услуг организациями в сфере культуры, охраны здоровья, образования, социального обслуживания и федеральными учреждениями медико-социальной экспертизы. В Воронежской области в 2018 г. были утверждены Положения ${ }^{43}$ и сформированы общественные советы. В 2019 г. в Воронежской областной Думе был впервые заслушан отчет губернатора Воронежской области А. В. Гусева о результатах независимой оценки качества условий оказания услуг организациями Воронежской области в сфере социального обслуживания, образования, здравоохранения, а также культуры за 2018 г. Обсуждение документа состоялось в рамках совместного заседания комитетов Воронежской областной Думы по труду и социальной защите населения, по охране здоровья, по культуре и историческому наследию, по образованию, науке и молодежной политике. По итогам проведенного обсуждения депутаты областной Думы рекомендовали исполнительным органам власти обеспечить выполнение планов мероприятий по устранению недостатков, выявленных в ходе независимой оценки и направить информацию об исполнении этих планов в Воронежскую областную Думу. Особое внимание региональный парламент рекомендовал обратить на повышение уровня доступности услуг в организациях для инвалидов и лиц с ограниченными возможностями здоровья, а также на привлечение этих категорий лиц к участию в независимой оценке ${ }^{44}$.

${ }^{42} \mathrm{O}$ внесении изменений в отдельные законодательные акты Российской Федерации по вопросам совершенствования проведения независимой оценки качества условий оказания услуг организациями в сфере культуры, охраны здоровья,

ح образования, социального обслуживания и федеральными учреждениями меди-

인 ко-социальной экспертизы : федер. закон от 5 декабря 2017 г. № 392-Ф3 // Собр. законодательства Рос. Федерации. 2017. № 50 (ч. 3). Ст. 7563.

${ }^{43}$ Об Общественном совете при департаменте здравоохранения Воронежской области по проведению независимой оценки качества условий оказания услуг медицинскими организациями : приказ Д3 Воронежской области от 27 июня 2018 г. № 1316. URL: http://www.govvrn.ru ; Об утверждении Положения об Обществен-

68 ном совете по проведению независимой оценки качества условий оказания услуг организащиями социального обслуживания при департаменте социальной защиты Воронежской области : приказ ДСЗ Воронежской обл. от 8 июня 2018 г. № 26/н. URL: http://www.govvrn.ru ; Об Общественном совете по проведению независимой оценки качества условий осуществления образовательной деятельности организациями, осуществляющими образовательную деятельность, при департаменте образования, науки и молодежной политики Воронежской области : приказ Департамента образования, науки и молодежной политики Воронежской области от 13 июня 2018 г. № 715. URL: http://www.govvrn.ru ; Об утверждении Положения об Общественном совете по проведению независимой оценки качества условий оказания услуг организащиями в сфере культуры : приказ ДК Воронежской области от 22 июня 2018 г. № 324-ОД. URL: http://www.govvrn.ru

${ }^{44}$ В Воронежской областной Думе представлен общественный рейтинг учреждений сощиальной сферы региона. URL: http://opvo36.ru/v-voronezhskoy-oblastnoy- 
Государственная власть. Законодательный процесс...

В 2019 г. Общественная палата области приступила к формированию общественных советов при исполнительных органах государственной власти в соответствии с действующим законодательством и в порядке, предусмотренном постановлением правительства Воронежской области ${ }^{45}$ и Положениями об общественных советах, утвержденных исполнительными органами государственной власти. В настоящее время сформированы 15 Общественных советов.

Для общественных советов при исполнительных органах государственной власти Воронежской области характерны недостатки, отмеченные Е. Г. Дьяковой и А. Д. Трахтенберг ${ }^{46}$. Тенденция, определенная на федеральном уровне, направленная на максимальное раскрытие потенциала общественных советов, через повышение их самостоятельности, независимости от органов власти, предотвращение конфликта интересов и ведомственного лоббизма, пока недостаточно отражается на региональном уровне.

\section{Общественный контроль за ходом выборов в органы местного самоуправления}

В Воронежской области Общественная палата неоднократно выступала инициатором проведения общественного контроля за ходом проведения выборов в органы местного самоуправления. В рамках подготовки и проведения выборов в Единый день голосования 8 сентября 2019 г. Общественной палатой Воронежской области совместно с Избирательной комиссией Воронежской области, при поддержке уполномоченного по правам человека и Регионального отделения «Ассоциации юристов России» была проведена учеба 150 общественных наблюдателей; подготовлены методические материалы для общественных наблюдателей; проведен онлайн-семинар с участием будущих наблюдателей, председателей муниципальных общественных палат районов, где должны были проходить выборы. В ходе семинара участники обсудили стандарты наблюдения на избирательных участках, методические рекомендации по избирательному законодательству, вопросы координации действий в день выборов ${ }^{47}$. В Единый день голосования 8 сентября 2019 г. на территории Воронежской области прошли выборы в органы местного самоуправления в 10 муниципальных районах Воронежской области на 117 избирательных участках. На каждом избирательном участке присутствовали независимые общественные наблюдатели, направленные от Общественной палаты Воронежской области. В целях обеспечения открытости и гласности избирательного процесса

dume-predstavlen-obshhestvennyiy-reyting-uchrezhdeniy-sotsialnoy-sferyi-regiona (дата обращения: 11.12.2019).

${ }^{45} \mathrm{O}$ Порядке образования общественных советов при исполнительных органах государственной власти Воронежской области : постановление правительства Воронежской области от 23 апреля 2019 г. № 399. URL: https://www.govvrn.ru

${ }^{46}$ См.: Дьякова Е. Г. Трахтенберг А. Д. Указ. соч. С. 74-75.

47 Общественный контроль на выборах в 2019 г. URL: http://opvo36.ru/ obshhestvennyiy-kontrol-na-vyiborah-v-2019-godu (дата обращения: 11.12.2019). 


\section{Вестник ВГУ. Серия: Право}

Общественной палатой Воронежской области была организована работа единого Информационно-справочного центра, который объединил работу «горячих линий» Избирательной комиссии Воронежской области, уполномоченного по правам человека в Воронежской области, Общественной палаты и Молодежной избирательной комиссии области. «Центр» осуществлял мониторинг сообщений и обращений граждан в социальных сетях и различных интернет-порталах. Выборы в Единый день голосования в области прошли без нарушений избирательных прав граждан ${ }^{48}$.

\section{Общественный контроль в муниципальных образованиях Воронежской области}

В муниципальных образованиях Воронежской области создана необходимая правовая база, позволяющая населению и институтам гражданского общества принимать участие как в процессе подготовки нормативных правовых актов органов государственной и муниципальной власти Воронежской области, так и в осуществлении местного самоуправления ${ }^{49}$. Общественная палата Воронежской области осуществляет взаимодействие с муниципальными общественными палатами, оказывает организационную и методическую помощь, организует и проводит семинары и совещания, учебу членов общественных палат муниципальных образований ${ }^{50}$.

Общественные палаты мунищипальных районов и городских округов ежегодно оценивают деятельность органов местного самоуправления. Председатели и члены муниципальных общественных палат входят в состав экспертных групп по оценке эффективности развития сельских поселений. Заслуживает внимания опыт работы Общественной палаты Россошанского района, члены которой принимают участие в работе пред-

구의 в ${ }^{48}$ Общестенный контроль вдиный день голосования в Воронежской обла-

Z сти. URL: http://opvo36.ru/obshhestvennyiy-kontrol-v-edinyiy-den-golosovaniya-vvoronezhskoy-oblasti (дата обращения: 11.12.2019).

${ }^{49} \mathrm{O}$ порядке осуществления гражданской инициативы в Воронежской области : закон Воронежской области от 27 июня 2007 г. № 85-О3 ; О народном обсуждении проектов нормативных правовых актов Воронежской области и важнейших вопросов социально-экономического развития Воронежской области : закон Воронежской области от 27 ноября 2008 г. № 120-О3 ; О некоторых вопросах проведения публичных мероприятий : закон Воронежской области от 17 декабря 2012 г. № 160-О3 ; О государственной (областной) поддержке социально ориентированных некоммерческих организаций в Воронежской области : закон Воронежской области от 6 октября 2011 г. № 134-О3 ; О регулировании отдельных вопросов осуществления общественного контроля в Воронежской области : закон Воронежской области от 5 июня 2015 г. № 103. URL: http://www.govvrn.ru

${ }^{50}$ См.: Агибалов Ю. В. Механизмы взаимодействия Общественной палаты Воронежской области, общественных палат мунищипальных образований и органов местного самоуправления Воронежской области // Механизмы взаимодействия общественных палат и органов местного самоуправления : материалы расширенного заседания Совета Общественной палаты Воронежской области / под общ. ред. Ю. В. Агибалова. Воронеж, 2016. С. 8-14. 
Государственная власть. Законодательный процесс...

ставительных органов местного самоуправления района ${ }^{51}$. В практику работы общественной палаты района вошло проведение выездных заседаний палаты в муниципальных образованиях, на которых рассматриваются актуальные вопросы населения, в том числе и ход реализации национальных проектов в районе. По инициативе общественной палаты района прошло выездное заседание Общественной палаты Воронежской области, посвященное вопросам организации общественного контроля в муниципальных образования ${ }^{52}$. В ряде мунищипальных образований общественные палаты участвуют в территориальном общественном самоуправлении (ТОC), осуществляют контроль за реализацией проектов, реализуемых ТОСами. ТОСы стали серьезным инструментом как для повышения гражданской активности населения, так и для решения конкретных проблем местного самоуправления. В области создано более 2 тысяч ТОСов, в деятельность которых было вовлечено более полумиллиона человек, было реализовано свыше 1,5 тыс. проектов. В то же время в области отсутствует системная работа по осуществлению общественного контроля в муниципальных образованиях. Общественные палаты не участвуют в формировании общественных советов при органах местного самоуправления, недостаточно внимания уделяют проведению общественной экспертизы проектов нормативных правовых актов и мониторингу действующего законодательства, правовому просвещению населения. Население не знает своих прав, многие никогда не читали уставы своих муниципальных образований и не знают о своих возможностях и формах осуществления ими местного самоуправления, кроме участия в выборах. И здесь большое поле деятельности для институтов гражданского общества. В своей работе общественные палаты муниципальных образований редко опираются на общественное мнение и общественный запрос. Отсутствие реальных рычагов воздействия на принимаемые властью решения еще больше снижает мотивацию граждан к участию в осуществлении местного самоуправления. В муниципальных образованиях области не работает институт правотворческой инициативы, отмечается низкая әффективность от проводимых публичных слушаний и общественных обсуждений. Муниципальные общественные палаты как институты общественного контроля должны не только принимать активное участие в публичных слушаниях при обсуждении проектов местных бюджетов и отчетов об их исполнении, планов и программ развития муниципальных образований и других важнейших вопросов местного значения, но и сами инициировать проведение общественных обсуждений и публичных слушаний, проведение общественных мониторингов по вопросам, волнующим жителей муниципального образования. Необходимо

${ }_{51}$ Члены Общественной палаты Россошанского муниципального района приняли участие в расширенной сессии депутатов районного Совета. URL: http:// opvo36.ru/chlenyi-obshhestvennoy-palatyi-rossoshanskogo-munitsipalnogo-rayonaprinyali-uchastie-v-rasshirennoy-sessii-deputatov-rayonnogo-soveta (дата обращения: 11.12.2019).

${ }_{52}$ Совещание по вопросам общественного контроля в Россошанском районе. URL: http://opvo36.ru/soveshhanie-po-voprosam-obshhestvennogo-kontrolya-v-rossoshanskom-rayone (дата обращения: 09.12.2019). 


\section{Вестник ВГУ. Серия: Право}

активнее использовать такие формы участия населения в осуществлении местного самоуправления, как сходы граждан, собрания и конференщии граждан, проведение опросов граждан для выявления мнения населения и его учета при принятии решений органами местного самоуправления по наиболее важным вопросам местного значения.

Проведенное исследование института общественного контроля в Российской Федерации позволило сделать следующие выводы:

1. В Российской Федерации приняты законы, регулирующие вопросы общественного контроля на федеральном и региональном уровнях, определены субъекты общественного контроля.

2. Ведущее место среди субъектов, осуществляющих общественный контроль, отводится общественным палатам. В Российской Федерации сформирована система общественных палат, состоящая из Общественной палаты РФ, общественных палат субъектов РФ и муниципальных общественных палат.

3. Функции общественного контроля призваны осуществлять общественные советы при органах государственной власти и местного самоуправления, формируемые общественными палатами совместно с органами власти.

Анализ практики формирования и работы субъектов общественного контроля на примере Воронежской области показал, что Общественная палата Воронежской области наделена широкими полномочиями по осуществлению общественного контроля. Действующее законодательство Воронежской области предоставило Общественной палате Воронежской области не только осуществлять общественный контроль за деятельностью органов власти, но и участвовать в формировании общественных советов при органах исполнительной власти, проводить мониторинг действующего законодательства и обращаться с законодательной инициативой в Воронежскую областную Думу. В то же время практика осу-

을 ществления общественного контроля Общественной палатой показала существующие пробелы в законодательстве. Тенденция, определенная на федеральном уровне, направленная на максимальное раскрытие потенциала общественных советов через повышение их самостоятельности, независимости от органов власти, предотвращение конфликта интере-

72 сов и ведомственного лоббизма, пока недостаточно отражается на региональном уровне. Общественные палаты муниципальных образований практически не участвуют в формировании общественных советов при органах местного самоуправления, недостаточно внимания уделяют проведению общественной әкспертизы проектов нормативных правовых актов и мониторингу действующего законодательства. Сегодня необходимо не только совершенствовать действующее законодательство, но и обеспечить учет мнения общественных палат при осуществлении правотворческой деятельности органов государственной власти, при рассмотрении результатов проведения Общественной палатой мониторинга действующего законодательства или независимой общественной экспертизы проектов нормативных правовых актов. 
Государственная власть. Законодательный процесс...

Для повышения роли Общественной палаты предлагается закрепить в областном законодательстве обязанность органов государственной власти и местного самоуправления рассматривать в порядке, установленном законом или регламентом органа власти, заключения по результатам общественной экспертизы, с непосредственным участием представителя Общественной палаты, проводившего экспертизу нормативно-правового акта. С такой с законодательной инициативой в областную Думу могла бы выйти Общественная палата Воронежской области. При наличии такой нормы, можно было бы оценивать работу Общественной палаты по осуществлению как общественной экспертизы, так и результатов мониторинга действующего законодательства. Общественной палате Воронежской области необходимо предоставить реальные права по формированию общественных советов при исполнительных органах государственной власти, а не только право объявлять конкурс об их формировании.

Муниципальные общественные палаты как институты общественного контроля должны инициировать проведение общественных обсуждений и публичных слушаний, общественных мониторингов по вопросам, волнующим жителей муниципального образования, участвовать в формировании общественных советов при органах местного самоуправления, сходах и собраниях граждан для выявления мнения населения по наиболее важным вопросам местного значения. Совершенствование работы по осуществлению общественного контроля, несомненно, потребует изменения действующего законодательства, принятия нормативных правовых актов органов государственной власти и местного самоуправления. Но эта работа должна проводиться с обязательным учетом мнения населения, выраженного, прежде всего, через существующие институты гражданского общества.

Воронежский институт экономики и социального управления, Российская академия народного хозяйства и государственной службы при Президенте Российской Федераиии (Воронежский филиал)

Агибалов Ю. В., кандидат экономи ческих наук, профессор кафедры государ ственного и муниципального управления

E-mail: ayv1957@yandex.ru
Voronezh branch of the Russian Presidential Academy of National Economy and Public Administration

Agibalov Yu. V., Candidate of Economics, Professor of the Economics State and Municipal Administration Department

E-mail:ayv1957@yandex.ru 